\title{
Comparison amid the Service Quality Attributes: Pakistan Hotel Industry Analysis
}

\author{
NASEEB SHAH \\ PhD Research Scholar, Institute of Business Studies and Leadership \\ Abdul Wali Khan University Mardan \\ naseeb_shah@hotmail.com \\ PROF. DR. QADAR BAKHSH BALOCH \\ Director, Institute of Business Studies and Leadership \\ Abdul Wali Khan University Mardan \\ qbbaloch@awkum.edu.pk \\ SOURATH \\ PhD Research Scholar, Institute of Business Studies and Leadership \\ Abdul Wali Khan University Mardan \\ sorathm@yahoo.com
}

Abstract

\begin{abstract}
Study focus was to comparatively analyze the expected and actual service quality attributes in the hotel industry of Khyber Pakhtunkhwa, Punjab and Islamabad, Pakistan. Population of the study was comprised of customers/clients of different hotels/ situated at urban areas of Khyber Pakhtunkhwa (KP), Lahore, and Islamabad Capital city of Pakistan. Statistical analysis reveals that there exist significance difference amid the customers/clients of KP, Lahore, and Islamabad Pakistan on expected and actual service quality attributes. The study considered that lodging client's/customers are the key factor in the friendliness and in up-bring the business prosperity.
\end{abstract}

Key Words: SERVQUAL, Hotel Industry, Customers

\section{Introduction}

Sustenance, convenience and dressing are the three most basic things of human. Hotels/Inn or lodging industry alone gives two fundamental things: sustenance and convenience. Hotels/Inn is a piece of the neighborliness business which is an umbrella term for a wide assortment of administration ventures including, however not restricted to, lodgings, eateries and gambling clubs. Lodging is frequently alluded as a "Home far from home". Hotels ordinarily offers a full scope of housing and administrations, which may incorporate suites, open dinning, feast offices, parlors and amusement offices. It is considered as an industry whose principle point is likewise to make benefits for the hoteliers, however this may change now and again. As per the Tourism and Hoteling industry Pakistan was placed in 47 out of 200 countries in an examination of the world travel and tourism committee improvement figures (Kandampully \& Juwaheer, 2009). Tourists are visit or spend more much of the time to Galiyat and Murree in view of quietness and stable peace circumstance (Al Khattab \& Aldehayyat, 2011). Study explores that very rare amount of studies on comparison of service quality attributes in Pakistan (Al Khattab \& Aldehayyat, 2011). In addition, the comparison or expected and actual service quality attribute in hotel industry is still vague (Kandampully \& Juwaheer, 2009; Al Khattab \& 
Aldehayyat, 2011). Notwithstanding that because of unseemly business execution of hotels/inn ventures and service/administration quality, lawfulness circumstance of Pakistan the development of lodging industry in Pakistan has been declined, therefore the clients can't pull in from any current and new sections of hotels/inn industry and are not feeling fulfilled. In order to cope up with this challenging situation the objectives of this study is a) to comparatively analyze the expected and actual service quality attributes in the hotel industry of Pakistan and b) to compare the mean score difference about the customers of KP, Punjab and Islamabad Pakistan. The investigation has inspiration to numerous perspectives, for example, a) Research expected to setting directing model for the administration of lodgings and cordiality industry. The rules reason for existing is to assist them with assessing and measure consumer loyalty and interior administration adequacy consequently empowering vital administration and conclusive stakeholders to learn.

\section{Literature Review}

Service Quality (SERVQUAL) attributes is as often as possible utilized instrument in estimating service/administration quality in the hotel/inn business along an arrangement of five measurements/factors. While building up this model Parasuraman (1985) at first recorded some administration related properties which were a) tangibility (Equipment, accommodation and uniform of staff), b) reliability (ability to deliver promised service), c) responsiveness (readiness of staff members to assist), d) competence (staff capability in executing service), e) courtesy (respect and politeness by staff), f) credibility (professional honesty, trustworthiness), g) security (safety from risk and physical danger), h) access (approachability of service provider), and communication (understanding communication).

Various examinations have hypothesized that SERVQUAL is multidimensional basically to measure hotel/lodging service/administration quality (Akbaba, 2006; Maria \& Serrat, 2011). Akbaba (2006) contemplated the administration nature of hotels/inns in Turkey by breaking down the service/administration quality in light of 29 attributes, which were connected from SERVQUAL, and the most essential factor mirroring the general needs of administration quality estimation was tangibility or substantial administrations. Wilkins et al. (2007) additionally examined the administration nature of lodgings in Australia. The seven variables were produced from SERVQUAL, covering style and comfort, room quality, extraordinary offers, quality staff, identity of customers, quick administration, and quality nourishment and refreshments.

Furthermore, other research has shown and clarified that the attributes of administration quality factors and administration needs, from the clients' point of view, varied relying upon the lodging writes. Gabbie and O'Neill (1997) directed research on the administration nature of lodgings in North Ireland. Their points were to examine the holes between the desire and the impression of administration quality conveyed by two 3-star inns utilizing 22 attributes of SERVQUAL. Carrillat et al (2007) found that SERVQUAL was an outstanding instrument, and turned into an appropriate estimation device for the lodging business, one of the administration organizations concentrating on consumer loyalty. Salazar et al.(2010) likewise built up an administration quality assessment scale for the neighborliness division. The greater part of the inquires about are discovered applying SERVQUAL demonstrate which rotated around the five service/administration quality measurements, for example, tangibility, reliability, responsiveness, assurance, empathy and customer service (Parasuraman, Zeithaml $\wedge$ Berry, 1888). Studies reported that there exists 
significant difference amid the expected and actual service quality attribute in the hotel industry is still vague (Al Khattab \& Aldehayyat, 2011; Saunders \&Thornhill, 2007).

\section{Methodology \\ 3.1 Population}

The populace outline for the investigation has been stratified on the bases of geography and the status level of the hotels/lodgings situated in chosen urban areas of Khyber Pakhtunkhwa, Islamabad and Lahore, Pakistan. Notwithstanding, the hotels/lodgings incorporated into the populace are those which have eateries and living settlement both. The example of lodging was involved 10 inns at every area and 20 clients at every inn were examined as respondents.

\subsection{Sample and Sample Frame}

Stratification depended on the geological/geographical premise with the strata of KP, Islamabad and Lahore, Pakistan. From that point, hotels/lodgings were stratified on the bases of their facilities and magnitude as well. The 1600 questionnaires were distributed conveniently amid the hotel customers of KP, Islamabad and Lahore, Pakistan and 1429 filled questionnaires were returned. Response was 89\% which was good (Sekaran, 2003). The researcher selected the respondents of the survey via convenient sampling technique. The numbers of constructs in the final questionnaire for this study were adopted from Boon and Rompho (2012) and modified suiting to local settings. Underneath is the table that depicts the sample frame.

Table 1: Sample

\begin{tabular}{lcccc}
\hline Cities & T. Hotels & $\begin{array}{c}\text { Questionnaire } \\
\text { Distributed }\end{array}$ & $\begin{array}{c}\text { Questionnaire } \\
\text { Returned }\end{array}$ & \%age \\
\hline Peshawar & 10 & 200 & 188 & 13.1 \\
Swat/Kalam & 10 & 200 & 178 & 12.4 \\
Chitral & 10 & 200 & 183 & 12.8 \\
Galiat & 10 & 200 & 171 & 11.9 \\
Naran/Shugran & 10 & 200 & 175 & 12.2 \\
Abbottabad & 10 & 200 & 177 & 12.3 \\
Islamabad & 10 & 200 & 165 & 11.5 \\
Lahore & 10 & 200 & 192 & 13.4 \\
\hline Total & $\mathbf{8 0}$ & $\mathbf{1 6 0 0}$ & $\mathbf{1 4 2 0}$ & $\mathbf{1 0 0}$ \\
\hline
\end{tabular}

\section{Analysis}

Table 2 Demographics

\begin{tabular}{lcc}
\hline \multicolumn{1}{c}{ Gender } & Frequency & Percent \\
\hline Male & 788 & 55.1 \\
Female & 641 & 44.9 \\
Total & 1429 & 100.0 \\
\hline \multicolumn{1}{c}{ Age } & Frequency & Percent \\
\hline 17-27 years & 823 & 57.6 \\
28-38 years & 151 & 10.6 \\
39 and above & 455 & 31.8 \\
Total & 1429 & 100.0 \\
\hline
\end{tabular}

The above captioned table represents the demographics of the respondents. 
4.2 Paired Sample T-test

Table 3: Expected and Actual Service Quality Comparison

\begin{tabular}{lcccccc}
\hline Pair & Mean & $\mathbf{N}$ & $\begin{array}{c}\text { Std. } \\
\text { Deviation }\end{array}$ & $\begin{array}{c}\text { Std. } \\
\text { Error } \\
\text { Mean }\end{array}$ & T & Sig \\
\hline Expected Tangibility- Actual & 3.56 & 1429 & .79986 & .02116 & 20.5 & .000 \\
Tangibility & 4.11 & 1429 & .88208 & .02333 & & \\
\hline Expected Reliability- Actual & 4.07 & 1429 & 1.01178 & .02677 & 4.99 & .000 \\
Reliability & 4.25 & 1429 & .98556 & .02607 & & \\
\hline Expected Responsiveness - & 4.34 & 1429 & .84089 & .02224 & 38.2 & .000 \\
Actual Responsiveness & 3.40 & 1429 & .79749 & .02110 & & \\
\hline Expected Assurance - Actual & 4.17 & 1429 & .78061 & .02065 & 16.8 & .000 \\
Assurance & 3.67 & 1429 & .84123 & .02225 & & \\
\hline Expected Empathy- Actual & 3.77 & 1429 & .73406 & .01942 & 3.37 & .001 \\
Empathy & 3.67 & 1429 & .81206 & .02148 & & \\
\hline Expected Customer Service- & 3.66 & 1429 & .59024 & .01561 & 22.8 & .000 \\
Actual Customer Service & 3.15 & 1429 & .98578 & .02608 & & \\
\hline
\end{tabular}

The outcomes of Paired samples t-test used for comparatively analyze the expected and actual service quality. As per statistical value consequence of actual and expected tangibility, $(t=20.5, p<.05)$, actual and expected reliability $(t=4.99, p<.05)$, actual and expected responsiveness $(t=38.2, p<.05)$, actual and expected assurance $(t=16.8, p<.05)$, actual and expected empathy $(t=3.37, p<.05)$ and actual and expected customer service $(t=22.8, \quad p<.05)$, there exist significance difference between expected and actual service attributes.

Table 4 Comparing the Mean Score of KPK, Punjab and Islamabad Customer

\begin{tabular}{lcccccc}
\hline Pair & Mean & $\mathbf{N}$ & $\begin{array}{c}\text { Std. } \\
\text { Deviation }\end{array}$ & $\begin{array}{c}\text { Std. } \\
\text { Error } \\
\text { Mean }\end{array}$ & $\mathbf{T}$ & Sig \\
\hline KP- Punjab & $0 f$ & & & & \\
& 4.12 & 1429 & .882 & .023 & 6.03 & .000 \\
\hline KP-Islamabad & 4.25 & 1429 & .986 & .026 & & \\
\hline Punjab-Islamabad & 3.40 & 1429 & .882 & .023 & 23.7 & .000 \\
& 3.25 & 1429 & .797 & .021 & & \\
\hline
\end{tabular}

The Paired samples t-test used to compare the mean score difference about the customers of KPK, Punjab and Islamabad Pakistan. As per statistical value consequence of KP and Punjab $(t=6.03, p<.05), \mathrm{KP}$ and Islamabad $(t=23.7, p<.05)$ and Punjab and Islamabad $(t=28.1, p<.05)$, there exist significance difference between the mean score about the customers on service quality attribute existence in KP, Punjab and Islamabad Pakistan.

\subsection{Discussion}

This research study was based on quantitative research technique to comparatively analyze the expected and actual service quality attributes in the hotel industry of Khyber Pakhtunkhwa, Punjab and Islamabad City of Pakistan. The data was collected from the 1429 hotel customers of Peshawar, Swat, Chitral, Naran, Abbottabad and Galiat cities of Khyber Pakhtunkhwa, (KPK), Lahore (Punjab) and Islamabad capital city Pakistan. The questionnaire was used for the data collection. Questionnaire was based on five point Likert Scale. Paired samples t-test used for 
comparatively analyze the expected and actual service quality. As per statistical value consequence, there exist significance difference between expected and actual service attributes i.e. (tangibility, reliability, responsiveness, assurance, empathy and customer satisfaction). The result of the study is consistent with the previous studies of (Saunders \& Thornhill, 2007; Zhang et al., 2011; Akibaba, 2005; Sohrabi et al, 2012). Moreover, the comparison amid the mean score difference about the customers of KP, Punjab and Islamabad Pakistan also exhibited that there exist significance difference between the mean score about the customers on service quality attribute existence in KP, Punjab and Islamabad Pakistan. The result of the study was consistent with the previous study of (Zhang et al., 2011; Akibaba, 2005).

\subsection{Conclusion}

Study focuses was to comparatively analyze the expected and actual service quality attributes in the hotel industry of Khyber Pakhtunkhwa, Punjab and Islamabad City of Pakistan. The first objective of the study was to comparatively analyze the expected and actual service quality attributes in the hotel industry of Pakistan. The paired sample t-test was used to accomplish the first objective and statistical result found that there exist significance difference between expected and actual service attributes i.e. (tangibility, reliability, responsiveness, assurance, empathy and customer satisfaction). The second objective of the study to compare the mean score difference about the customers of KP, Punjab and Islamabad Pakistan. In order to measure the second objective of the study researcher also used paired sample t-test and statistical consequences exhibited that there exist significance difference between the mean score about the customers on service quality attribute existence in KP, Punjab and Islamabad Pakistan.

The study considered that hotel customers services and its experience is the key factor in the hospitality industry. Customers who perceive positive experience to express positive intention revisit the place again and also recommend others to visit the same destination. Similarly positive service experience of the customers increases the level of satisfaction which reduces the number to customer's complaints in the hospitality industry. Similarly customers will not perceive positive experience unless the customers feel that service is better and greater than the money paid. Finally concluding the whole research conducted, it is found that service quality attributes i.e. tangibility, reliability, responsiveness, assurance, empathy and customer satisfaction are the significant predictors of hospitality Industry.

\subsection{Recommendations}

It is recommended that a) services such as online booking, customer care and online car hire services should be availed online to improve the quality of customer service, b) suggestion box should be strategically put a point where customers can note them, c) set up an effective communication channel, d) the hotel management should regularly conduct audits in order to ensure accountability in the use of hotel resources, e) establish an effective Information management system and f) allow for employee participation in strategic planning

\subsection{Limitations}

There are certain limitations of this study. First and the primary limitation is that this research study is cross sectional in the nature. Second major limitation is the small obtained sample size which is selected from only from hotels of KPK, Pakistan. Third limitation was the unavailability of the literature encompassing the variables of the study. 


\subsection{Future Area}

The area for additional and further research is, an in-depth examination of more hotels factors in Pakistan that contributing towards the service quality. In future the present hypotheses should be studied in numerous samples from different other organizations of Pakistan on longitudinal basis with inclusion of some moderation and mediating variables.

\section{References}

Akibaba, A. (2006). Measuring service quality in the hotel industry: A study in a business hotel in Turkey.International Journal of Hospitality Management $25(2), 170-192$

Akibaba, A. (2006). Measuring service quality in the hotel industry: a study in a Business hotel in Turkey.Hospitality Management, 170-192

Al Khattab, S. A., \& Aldehayyat, J. S. (2011).Perceptions of service quality in Jordanian hotels. International Journal of Business and Management, 6(7), p226.

Baloch, Q. B. \& Rehman, A. (2015). Regional Integration of Pakistan Tourism: Exploring Prospects. Abasyn University Journal of Social Sciences 8(20

Baloch, Q. B. (2007). Managing tourism in Pakistan: A case study of Chitral valley. Journal of Managerial Sciences, 2(2), 169-190.

Bloemer, J. (1999). Linking perceived service quality and service loyalty: a multidimensional perspective. European Journal of Marketing, 33(11, 12), 10821106.

Boon, S. \& Nopadol, R. (2012). Measuring Service Quality Dimensions: An Empirical Analysis of Thai Hotel Industry. International Journal of Business Administration.3 (5); 52- 63

Bowen \& Shoemaker. (1998). Loyalty: a strategic commitment, Cornell Quarterly, 2 $: 12-25$

Briggs, R. (1997). Advertising on the web: is there response before click-through. Journal of Advertising Research, 37(2), 33-45.

Brogowicz, A. A., Delene, L. M., \& Lyth, D. M. (1990). A synthesized service quality model with managerial implications. International Journal of Service Industry Management, 1(1), 27-45.

Cadotte, E., \& Turgeon, N. (1988). Key Factors in Guest Satisfaction, Cornell Hotel and Restaurant Administration Quarterly, 28, 44-51

Cadotte, E.R., Woodruff, R.B. \& Jenkins, R. L. (1987). Expectations and Norms in Models of Consumer Satisfaction, Journal of Marketing.24 (3) 305-14.

Caruana, A. (2002). Service Loyalty: The Effects of Service Quality and the Mediating role of Customer Satisfaction.European Journal of Marketing, 36(7), 811-828.

Choi, T.Y., \& Chu, R. (2001). Determinants of hotel guests' satisfaction and repeat patronage in the Hong Kong hotel industry.Journal of Vacation Marketing, 20, 277-297

Cronin Jr, J. J., \& Taylor, S. A. (1992).Measuring service quality: a reexamination and extension. The journal of marketing, 55-68.

Dabholkar, P. A., Shepherd, C. D., \& Thorpe, D. I. (2000). A comprehensive framework for service quality: an investigation of critical conceptual and measurement issues through a longitudinal study. Journal of retailing, 76(2), 139-173. 
Dolnicar, S. (2002). Business travellers' hotel expectations and disappointments: a different perspective to hotel attribute importance investigation. Asia Pacific Journal of Tourism Research, 7(1), 29-35.

Ehrenberg, A. S. C. \& Goodhardt G. (2000). New brands: near-instant loyalty. Journal of Marketing Management, 16(6), 607-617.

Fiaz, Q. \& Baloch, Q. B. (2017). Reviving Tourism through Entrepreneurial Capabilities in Swat, Dir \& Chitral Triangle in Post Operation Environment. Journal of Managerial Sciences, 11(2).

Fornell \& Wernerfelt. (1987). Defensive marketing strategy by customer complaint management: A theoretical analysis. Journal of marketing research, 24 (November): $337-346$

Getty, J.M \& Thompson, K.N. (1994). The relationship between quality, satisfaction, and recommending behaviour in lodging decision. Journal of Hospitality \& Leisure Marketing, 2 (3): 3-22.

Gronroos (1988). Service quality: the six criteria of good perceived service quality. Review of Business. 9(3): 10-13

Gronroos, C. (1978). A Service-Oriented Approach to Marketing of Services, European Journal of Marketing, 12 (8), 588-601

Grönroos, C. (1983) Strategic Management and Marketing in the Service Sector. Marketing Science Institute. Boston, MA.

Grönroos, C. (1984). A service quality model and its marketing implications.European Journal of marketing, 18(4), 36-44.

Grönroos, C. (1994). From marketing mix to relationship marketing: towards a paradigm shift in marketing. Management Decision, 32(2), 4-20.

Gronroos, C. (2000). Service management and marketing - a customer relationship management approach, Chichester: John Wiley \& Sons

Gronroos. (1991). Strategic Management and Marketing In the Service Sector, Student literature-Chartwell-Bratt, Sweden.

Gummesson, E. (1991). Service quality: a holistic view. In Brown, S.W., Gummesson, E., Edvardsson, B., \&Gustavson, B. (Eds.), Service quality (pp. 3-22).Lexinton Books, Lexington, MA.

Haywood-Farmer, J. (1988). A Conceptual Model of Service Quality, International Journal of Operations \& Production Management, 8(6), 9-29.

Heskett, J.L., Jones, T.O., Loveman, G.W. Sasser, W.E. \& Schlesinger, L.A. (1994). putting the service profit chain to work, in: Harvard Business Review, MarchApril, 164-174.

Heskett, J.L., Sasser, W.E. \& Schlesinger, L.A. (1997). The service profit chain: how leading companies link profit and growth to loyalty, satisfaction, and value, New York: The Free Press.

Heskett, J.L., W.E. Sasser, \& L.A. Schlesinger (20030., The value profit chain: treat employees like customers and customers like employees, New York: The Free Press

Hu, H. H., Kandampully, J., \& Juwaheer, T. D. (2009). Relationships and impacts of service quality, perceived value, customer satisfaction, and image: an empirical study. The Service Industries Journal, 29(2), 111-125.

Jamal, A., \&Naser, K. (2002). Customer satisfaction and retail banking: an Assessment of Some of the Key Antecedents of Customer Satisfaction in Retail Banking. International Journal o Bank Marketing, 20(4):146-160. 
Jay Kandampully, \&DwiSuhartanto, (2000). Customer loyalty in the hotel industry: the role of customer satisfaction and image. International Journal of Contemporary Hospitality Management, 12 (6): 346 - 351

Johnston, R., Silvestro, R., Fitzgerald, L. \& Voss, C. (1990). Developing the determinants of service quality, in Langeard, E. and Eiglier, P. (Eds), Marketing, Operations and Human Resources Insights into Services, First International Research Seminar on Services Management, InstitutAdministration des Entreprises, Aix-en-Provence, pp. 373-400

Julander, M. J. \& Lindqvist. (1997). Linking customer satisfaction to financial performance data. in Edvardsson et al. (Eds) Advancing Service Quality: A Global Perspective, Conference Processing, University of Karlstad, Sweden,. 301-10.

Kandampully, J., \&Suhartanto, D. (2000). Customer loyalty in the hotel industry: the role of customer satisfaction and image. International journal of contemporary hospitality management, 12(6), 346-351.

Kang, G. D., \& James, J. (2004). Service quality dimensions: an examination of Grönroos's service quality model. Managing Service Quality: An International Journal, 14(4), 266-277.

Karunaratne, W. M. K. K., \&Jayawardena, L. N. A. C. (2010).Assessment of customer satisfaction in a five star hotel-a case study. Tropical Agricultural Research, 21(3), 258-265.

Kotler, P .(2000). Marketing Management. 10th edn., New Jersey, Prentice-Hall.

Kumar, M., Kee, F. T. \&Manshor, A. T. (2009). Determining the relative importance of critical factors in delivering service quality of banks; An application of dominance analysis in SERVQUAL model, Managing Service Quality, 19(2), 211-228.

Ladhari, R. (2009). A review of twenty years of SERVQUAL research..International Journal of Quality and Service Sciences, 1(2), 172-198.

Lehtinen, U. and Lehtinen, J.R., (1991). Two approaches to service quality dimensions, The Service Industries Journal. 287-303.

Liljander \& Strandvik (1993). Estimating Zones of Tolerance in Perceived Service Quality and Service Value, International Journal of Service Industry Management, 4(2): 6-28.

Mittal, V., \& Kamakura, W.A. (2001). Satisfaction, Repurchase Intent, and Repurchase Behavior: Investigating the Moderating Effect of Customer Characteristics, Journal of Marketing Research, 38(1):131-142.

Oliver, R. L. (1980). A Cognitive Model of the Antecedents and Consequences of Satisfaction Decisions', Journal of Marketing Research, 17(4) 460-69.

Oliver, R.L. (1981). Measurement and Evaluation of Satisfaction Processes in Retail Settings.Journal of Retailing. 57 (2) 25-48.

Oliver, R.L. (1997). Satisfaction: A Behavioral Perspective on the Consumer. McGraw Hill, New York

Parasuraman, A., Berry, L.L. \& Zeithaml, V.A. (1991). Refinement and Reassessment of the SERVQUAL Scale' Journal of Retailing. 67(4) 420-50.

Parasuraman, A., Zeithaml, V. \& Berry, L (1988). SERVQUAL: A multiple item scale for measuring customer perceptions of service quality. Journal of Retailing, 64(1), 12-40. 
Parasuraman, A., Zeithaml, V. A., \& Berry, L. L. (1985).A conceptual model of service quality and its implications for future research. the Journal of Marketing, 41-50.

Parasuraman, A., Zeithaml, V.A. \& Berry, L.L. (1986). SERVQUAL: A MultipleItem Scale forMeasuring Customer Perceptions of Service Quality. Working Paper ReportNo 86-108, Cambridge, MA: Marketing Science Institute.

Parasuraman, A., Zeithaml, V.A. \& Berry, L.L. (1988). SERVQUAL: A MultipleItem Scale for Measuring Consumer Perceptions of Service Quality', Journal of Retailing. 4 (1) 12-37.

Reichheld, \& Sasser, (1990). Zero defections: quality comes to services. Harvard Business Review, September-October: 105-11

Sachdev, S. B., \&Verma, H. V. (2004). Relative importance of service quality dimensions: a multisectoral study. Journal of services research, 4(1), 93-116.

Sasser, W.E., Olsen, R.P. \& Wyckoff, (1978). Management of Service Operations. Allyn\& Bacon, Boston

Saunders, M., Lewis P. \& Thornhill A. (2009). Research Methods for business students(4th ed) Pearson education limited

Thomas, R. (1997). Quantitative Methods for Business Studies, Hemel Hempstead: Prentice Hall.

Valarie A. Zeithami, A. Parasuraman \& Leonard L. Barry. (1990). Delivering Quality Service: Balancing Customer Perceptions and Expectations. The Free Press

Van Ree, H.J. (2002). The added value of office accommodation to organizational performance, in: International Journal of Productivity and Performance Management, 51(7): 357-363

Vuorinen, I., R. Jarvinen, \& U. Lehtinen (1998). Content and measurement of productivity in the service sector, in: International Journal of Service Industry Management, 9 (4): 377-396

Wilkinson, D. \& Birmingham, P. (2003). Using Research Instruments: A Toolkitfor Researchers, London: RoutledgeFalmer.

Wu, C.H., Liao, H., Hung, K., \& Ho, Y. (2012). Service guarantees in the hotel industry: Their effects on consumer risk and service quality perceptions. International Journal of Hospitality Management, 31(3), 757-763

Yang, Z., Peterson, R. \& Cai, S. (2003). Service quality dimensions of Internet purchasing: An exploratory analysis, Journal of Service of Marketing. 17. 685-698.

Zhang, Z., Ye, Q., \& Law, R. (2011). Determinants of hotel room price: An exploration of travelers' hierarchy of accommodation needs. International Journal of Contemporary Hospitality Management, 23(7), 972-981 